\title{
ARTICLES
}

\section{Global South at 50 and beyond?: The Voice from China for Establishing NIEO*}

\author{
An Chen $^{* *} \&$ Fan Yang ${ }^{* * *}$
}

\begin{abstract}
The great career of Global South-South Coalition has just entered its fifties, if we take the establishment of Group 77 in 1964 as its origin. For the past five decades, the course of SSC has seen its ups and downs. Confucian philosophy of China advocates for a comprehensive self-reflection every decade, so as to comb past experience for the sake of future self-improvement. At this historical turning point, it is of necessity to retrospect, while bearing contemporary international economic circumstances in mind, the SSC's past accomplishments and difficulties, in order to re-affirm people's confidence of this long-term strategy, and to avoid tactical short-sightedness. In this way, the career of Global SSC could hopefully get ready to sail out once again for new accomplishments. For Chinese scholars, it is also their responsibility to review the New China's self-positioning on the course of SSC, and to make the world academia hear a voice from China.
\end{abstract}

* This paper is a fully revised and updated version of Professor An Chen's written comment on the topic, "Global South: at 50 and Beyond" under the generous invitation of H.E. Boutros Boutros-Ghali, former UN Secretary-General and the Chairman of the Honorary Council of the European Center for Peace and Development ("ECPD") in collaboration with the Group 77 in order to celebrate its fiftieth anniversary in 2014.

DOI: http://dx.doi.org/10.14330/jeail.2015.8.1.04

** Senior Professor of Law School, Xiamen University School of Law; Chairman, Chinese Society of International Economic Law ("CSIEL") from1993 to 2011; Honorable Chairman of CSIEL from 2012 to present; International Arbitrator, selected and designated by the Chinese government to the International Centre for Settlement of Investment Disputes ("ICSID") under the Washington Convention since 1993. ORCID: http://orcid.org/0000-0001-5837-7511. The author may be contacted at chenan@xmu.edu.cn / Address: School of Law, Xiamen University, P.O. Box 978, 422 Siming Nan Road, Xiamen City, Fujian Province, 361005 P.R. China.

*** Ph.D. candidate of International Economic Law, Xiamen University. J.M. (“CUPL”), LL.M. (Hamburg). ORCID: http://orcid.org/0000-0001-8452-5231. He may be contacted at onosefan@163.com 


\section{Keywords}

South-South Coalition, NIEO, Group 77, International Economic Law, International Financial Order, China's Positioning

\section{Introduction: SSC at the age of "Knowing the Decrees of Heaven"}

While summarizing his own life course, Master Confucius said, "At fifteen, I had my mind bent on learning. At thirty, I stood firm. At forty, I had no doubts. At fifty, I knew the decrees of Heaven. At sixty, my ear was an obedient organ for the reception of truth. At seventy, I could follow what my heart desired, without transgressing what was right." ${ }^{\text {"1 }}$ As per this succinct summary, the career of the Global South-South Coalition ("SSC"; 南南联合自强 in Chinese) is now entering the life stage of "knowing the decrees of Heaven," if one reckons the establishment of Group 77 in 1964 as its origin.

According to popular opinions among Confucian scholars, the phrase "knowing the decrees of Heaven" means that "one begins to realize his lifetime mission, and endeavours to accomplish it." ${ }^{\prime 2}$ On this point, however, individuals and organizations take on different characteristics. Generally speaking, for individuals, it could take decades' accumulation of life experience before one can gradually make sense of his/her own lofty mission. For a wise man like Confucius, this process had taken 50 years. In the meantime, most organizations are created with a purpose. As per the Charter of Algiers of G77, the SSC career comprises of three categories of missions: (1) on the political level, it is to fully realize the independence of South countries; (2) on the economic level, it is to promote cooperation and common growth among South countries in such fields like trade, investment, finance and development aid; and (3) on the technical level, it is to encourage the exchange and proliferation of

1 吾十有五而志于学, 三十而立, 四十而不惑, 五十而知天命, 六十而耳顺, 七十从心所欲不逾矩. See ConfucIus, II The ANALECTS, ch. IV (Wei Chang ed., J. Legge trans. ), available at https://ebooks.adelaide.edu.au/c/confucius/c748a/ complete.html (last visited on Apr. 18, 2015).

2 See, e.g., Peirong Fu, Reading the Analects, available at http://blog.sina.com.cn/s/blog_4a57bcc9010004zi.html (last visited on Apr. 17, 2015). FU ascribes the source of this kind of mission to the Heaven, referring to "decrees of Heaven."

3 See Joint Declaration of the Group of 77 [EB/OL] (June 15, 1964), available at http://www.g77.org/doc/Joint\%20 Declaration.html; Charter of Algiers [EB/OL] (1967-10-25) Nov. 12, 2014, available at http://www.g77.org/doc/ algier 1.htm (all last visited on Apr. 17, 2015). 